\title{
William Forrest: Poetry, politics, script and power ${ }^{*}$
}

\author{
A. S. G. Edwards \\ The University of Kent, UK, Emeritus
}

\begin{abstract}
This article examines the poetic and scribal activities of the sixteenthcentury poet and scribe William Forrest. Forrest's works survive in a number of manuscripts that he prepared himself, some for presentation to specific individuals, some for less definable purposes. The article assesses his achievements as a scribe and manuscript producer over several decades. KEYWORDS: William Forrest; manuscript; autograph; poetry; paleography

William Forrest: poesía, política, letra y poder $^{* *}$

RESUMEN: Este artículo examina las actividades poéticas y como escriba del poeta y escriba del siglo XVI William Forrest. Las obras de Forrest sobreviven en varios manuscritos que preparó él mismo, algunos para presentarlos a personas específicas y otros para propósitos menos claros. El artículo evalúa sus logros como escriba y productor de manuscritos durante varias décadas.

William Forest:

Poesia, política, manuscrito e poder ${ }^{* * *}$

RESUMO: Este artigo examina as atividades poéticas e manuscritas do poeta e escriba quinhentista William Forest. As obras de Forest sobrevivem num conjunto de manuscritos preparados por ele próprio, alguns para serem apresentados a indivíduos específicos, outros com propósitos menos claros. $\mathrm{O}$ artigo avalia o seu trabalho como escriba e como produtor de manuscritos ao longo de várias décadas.
\end{abstract}

PALABRAS ClAVE: William Forrest; manuscrito; autógrafo; poesía; paleografía.
PALAVRAS-CHAVE: William Forest; manuscrito; autógrafo; poesia; paleografia.

\footnotetext{
"A version of this paper was delivered at the conference, "The Lerned Clerk" at Bates College, 10 July 2015. I am indebted to Professor Sylvia Federico for the invitation and to my colleagues at this stimulating event for their observations. I am indebted to Professor Julia Boffey for various corrections and am also grateful to Professor R. F. Yeager for helpful comments.

** Translation into Spanish by Tamara Pérez-Fernández

*** Translation into Portuguese by Miguel Ramalhete.
}

(C) ederi 29 (2019: 163-78) 
The activities of William Forrest (fl. 1530-1576) have received little attention from literary historians of the sixteenth century. Such facts of his life as are recoverable can be summarized swiftly. ${ }^{1} \mathrm{He}$ was born in the early sixteenth century (the date is unknown) and attended Cardinal College (now Christ Church) in Oxford in the 1530s. He was ordained priest and became a petty canon at Osney Cathedral in Oxfordshire, receiving a pension when it was dissolved in 1546. After the accession of Mary Tudor, he claims to have become one of her chaplains (although documentary evidence is lacking). Subsequently, in 1556, he became parson of Bledlow in Buckinghamshire, a position he retained under Elizabeth and only resigned in 1576 at what must have been a fairly advanced age (Young 1964). The date of his death is unrecorded.

These facts suggest that Forrest possessed a level of adroitness in the rapidly changing circumstances during which he lived. Through four reigns and changing doctrines he held various priestly roles without any apparent setbacks. If he was a chaplain of Mary Tudor the fact seems to have had no discernibly harmful consequences after Elizabeth's succession. It appears that Forrest had some skill in the politics of survival.

He was also a cleric of evident learning and culture. He owned a number of manuscripts. Among these were Cambridge, Trinity College MS B. 1. 18, the contents of which include fifteenth-century copies of Richard Rolle's Emendatio Vitae and of Hugh of St Victor (James 1900, I, 20-21), to which he added a few of his own verses. ${ }^{2}$ In addition, he had a twelfth-century manuscript from Thame Abbey, which included writings of Anselm of Canterbury and other theological works and which survives now in detached portions as various British Library Burney manuscripts. ${ }^{3} \mathrm{He}$ also owned an early sixteenth-century Sarum hymnal, now Oxford, St John's College, MS

\footnotetext{
1 These facts are outlined in the article on Holmes (2007), that is significantly dependent on the account of Forrest by Emden $(1974,209-10)$.

${ }^{2}$ Forrest has added eight lines of verse in his own hand on fol. 103v: "Who liste be fedde in the fode spirituall, | of sweete internall Contemplation.| heere maye be spedde in sorte moste speciall:| thorowe goddess divine inspiration, | thoughe layde Aparte in sundrye Nation.| In readynge heere of hampole and of hughe | it may to some geve goode occasion: | this worldes vayne pleasures the lesse to ensue." Printed in James (I, 21) with some variations from my own transcription above.
}

${ }^{3}$ Burney MSS 246, 285, 295, 341, 344, 357; see Ker (1937-1938, 134-35). 
60 (Hanna 2002, 80-81), and an important collection of Tudor masses, now Bodleian Music School E. 376-81; this comprises six paper part books, begun ca.1528-1530. It is possible that Forrest may have partly responsible for its transcription. ${ }^{5}$

Forrest's literary interests extended beyond the manuscripts he owned. His own writings offer evidence of a considerable acquaintance with literature contemporary and past. His evident interest in religious music may make it unsurprising that he shows a familiarity with the psalm translations of Thomas Sternhold (15001549). ${ }^{6}$ More striking is the fact that he is the first person known to have commented on the poetic achievements of Henry Howard, earl of Surrey. ${ }^{7}$ He speaks admiringly of the poet and dramatist, John Heywood, ${ }^{8}$ and seems to have had some form of relationship with George Cavendish, the poet and biographer of Cardinal Wolsey. ${ }^{9} \mathrm{He}$ also appears to have been on close terms with the poet and translator Alexander Barclay, successively Benedictine monk, Franciscan friar and, after the Reformation, beneficed clergyman until his death; he

\footnotetext{
${ }^{4}$ These are numbered, in order, D, A, T, B, Q, S; Forrest's name and the date "1530" appear on fol. 1 of A; for a description see Census-Catalogue of Manuscript Sources of Polyphonic Music, 1400-1550 (1979-1988, II, 292-94).

${ }^{5}$ See further Bergsagel (1963). See most recently the information and digital facsimiles on DIAMM at https://www.diamm.ac.uk/sources/2285/\#/

${ }^{6}$ He alludes to Sternhold in the heading to his Psalm translations in British Library MS Royal 17. A. xxi, fol 5 where they are described as "added to maister Sterheholids and others;" the passage is printed in W. D. Macray's edition of Forrest's The History of Grisild the Second $(1875,179)$.
}

${ }^{7}$ Forrest speaks of the poet in BL Royal 18. C. xiii, fol. 2v:

Callynge vnto mynde yeat better aduysement,

your noble ffather, Earle of Surraye

howe (in his tyme) to Bookes he was bent

and also endytynge many a vyrylaye $[\ldots]$.

${ }^{8}$ He mentions Heywood in British Library MS Add. 34791, fol. 3:

For learnynge Heywoode and I be neare one,

But for conveyaunce of a fyne sentence

He shall have my prayse of all to Rome hense.

He includes in British Library, MS Harley 1703, fols 108-9 a poem of twenty 4-line stanzas titled "A discription of A most nobel ladye |advowed by Iohn Heywoode presently | who aduertisinge her graces as said | saith of her thus, in much eloquent phrase [Incipit] Geue place, ye ladyes all bee gone;" see also Graves (1923).

${ }^{9}$ On possible links between Cavendish and Forrest see Sylvester (1959, 259-68). 
mentions him several times. ${ }^{10} \mathrm{He}$ also alludes to the by then traditional collocation of Chaucer, Gower and Lydgate. ${ }^{11}$ Forrest's acquaintance with Lydgate's corpus may have been more extensive than such a conventional allusion might suggest: he appears to have known his Fall of Princes, for instance. ${ }^{12}$

Forrest's own writing show that he was also, at times, a first-hand observer of contemporary events. By his own report he attended the debates about the validity of Henry VIII's marriage to Catherine of Aragon at Oxford in the 1530s: "I sawe it trulye [...] I was present and herde their complaynte" (Forrest 1875, 77-78). He also appears to have been present at the funeral of Catherine in 1536, of which he gives a detailed account (Forrest 1875, 120-22). Such direct experience provided the subject for some of his own poetry. It also possibly contributed to an awareness of political realities that is partly reflected in the content of some of his writings and in some of the contemporary dedications of his own manuscripts to particular figures of contemporary significance (a point to which I will return).

The range of Forrest's writings and their chronology require some summary. In the course of his clerical life he found the opportunity to compose a number of generally substantial works in verse. These mainly survive in manuscript. Only a couple of short poems were printed during his lifetime. ${ }^{13}$ This corpus amounts to between roughly twenty-five and thirty thousand lines of verse. And it is possible that there were once both further copies of surviving works and of other works now lost. ${ }^{14}$ No part of his larger corpus is available in a satisfactory form in a modern edition.

${ }^{10}$ Forrest refers at length to Barclay in Royal 18 C. xiii, fol. 2r-v and Harley 1703, fols

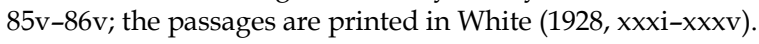

11 The passage, on fol. 3, is printed in Forrest $(1875,167)$.

${ }^{12}$ At one point in his Psalm translations he talks with casual intimacy about Lydgate's relationship with Humfrey, duke of Gloucester, the patron of Lydgate's poem. The passage, from British Library, MS Royal A. xxi, is printed in Forrest $(1875,178)$.

${ }^{13}$ The only poems published in his lifetime were a poem celebrating Mary's accession, A new ballade of the marigolde (1553; STC 11186), in single sheet folio and his versifications of the Pater Noster and Te Deum, again addressed to Queen Mary, which appear in the first edition of Foxe's Acts and Monuments (1563, 1139-40).

${ }^{14}$ Anthony Wood, Athenae Oxonienses (1691, col. 95) records among Forrest's works in the possession of "Robert, Earl of Alesbury" two manuscripts "Poems upon several Occasions-MS. fol" and "Certain meditations and Prayers necessary of a Christian - 
The nature and chronology of his verse oeuvre can be established with relative clarity. His earliest work is his History of the Patriarch Joseph, which was apparently completed sometime between 15431547, around the period when he was pensioned off from Osney. ${ }^{15} \mathrm{He}$ describes it in the Preface (fol. 3) as "the firste I ever sett for the." It survives in British Library, MS Add. 34,791, of a hundred and sixteen leaves, and is dedicated to William Parr, created earl of Essex in December $1543 .{ }^{16}$

In 1548 Forrest began the composition of The pleasaunt poesye of princelie practice, a work in the Advice to Princes tradition, addressed to Edward Seymour, duke of Somerset, Lord Protector to Edward VI. This appears uniquely in British Library, MS Royal 17. D. iii, a manuscript of seventy-seven leaves. ${ }^{17}$ The text breaks off abruptly partway through Chapter 24, stopping near the top of a recto leaf, after nearly four thousand lines, in rhyme royal stanzas. (The table of contents lists a total of 37 chapters.) Forrest may have abandoned it after Somerset's arrest for treason in October 1549. By $1551^{18}$ he had also prepared a metrical version of forty-eight Psalms (fols $5-77 \mathrm{v}$ ) followed by "The ffowre special canticles" (fols 77v-83). This collection is also dedicated (fols 1-3) to Protector Somerset, and is now

MS. fol. In prose and verse;" neither of these can be identified among those manuscripts of Forrest's works that now survive. In addition, Edmund Bernard, Catalogi librorum manuscriptorum Angliae et Hiberniae (1697) records among "Librorum Manuscriptorum Ecclesie Westmonasterensis Catalogus," "Some Psalms in English Verse by W. Forest" (II, 1315.225); this was destroyed in a fire in the late seventeenth century; see Robinson and James $(1909,57)$. The Dictionary of National Biography asserts that "a copy of both parts [of the History of Joseph] in one folio volume of 286 pages, written on paper, is in the possession of the Rev. J. E. A. Fenwick, at Thirlestane House, Cheltenham, being in the collection of Sir Thomas Phillipps, which that gentleman inherited." This manuscript has not been located. It cannot be identified with Bodleian Library MS Eng. poet. d. 9 (olim Phillipps 8909), a paper manuscript of 161 leaves. In addition, the following entries appear in a sale catalogue, Bibliotheca illustris sive catalogus variorum librorum [...], issued by T. Bentley and B. Walford in London on 21 November 1687, under "Manuscripts in English, in Folio": "25. William Forrest Chaplain to Queen Mary his History of Joseph, in old English Verse - 26 Another Volume of his Poems upon Several Occasions."

${ }^{15}$ For a recent discussion of the dating see Wort (2017).

${ }^{16}$ It has been edited by Mehok (1971, 1481A).

17 The text of this work was edited by Manzalaoui (1977, 390-534); the promised commentary volume has never appeared.

${ }^{18}$ Fol. 5 is headed "Certain Psalmes of dauyd [...] by William fforeste, 1551." 
British Library, MS Royal 17. A. xxi, a small manuscript of eightythree leaves. ${ }^{19}$

By 1558 Forrest had finished his History of Grisild the Second, a biography, or quasi-hagiography, again in rhyme royal, of the life of Katherine of Aragon, mother, of course, of the then Queen, Mary Tudor; what appears to be a presentation manuscript of this poem to Mary herself survives uniquely in Bodleian Library, MS Wood empt. 2 , of seventy-seven leaves. ${ }^{20}$

After this Forrest seems to have embarked on the preparation of a revised version of his History of the Patriarch Joseph completed around 1569, the first part of which is now Oxford, University College MS 88, of ninety-seven leaves; the second is British Library, MS Royal 18 C. xiii, of eighty-nine leaves. Both parts are dedicated to Henry Howard, duke of Norfolk. There is a further manuscript of this work in Bodleian Library MS Eng. poet d. 9 (olim Phillipps 8909), of a hundred and fifty-seven leaves, which has an explicit "ffinis .1569. die vero aprilis 11" (fol. 157). ${ }^{21}$ His last surviving major work seems to have been British Library, MS Harley 1703, a collection of Marian verse of various kinds, of a hundred and fifty-three leaves; this is dated in its colophon "ffinis 27 Octobris 1572 | per me Guilelmum forrestum" (fol. 153). ${ }^{22}$ Not all the poems in this manuscript are by Forrest himself; one poem, for example, is identified there as by "a devoute Scotte," sometimes incorrectly identified as William Dunbar. ${ }^{23}$ Forrest only infrequently identifies himself as author by his name or initials. ${ }^{24}$

\footnotetext{
${ }^{19}$ For discussion of these Psalm translations see Wort (2016a).

${ }^{20}$ The 1875 edition of this manuscript, by Macray, is not always accurate in transcription and almost wholly without commentary, but has a helpful Introduction, including a listing of Forrest's manuscripts. For a recent discussion of the date of the work see Wort (2016b).

${ }^{21}$ Wort (2017) suggests that these manuscripts contain different versions of the text, but does not present evidence for this view.

22 Edited by Keenan (1960); see Dissertation Abstracts International, 21 (1960), p. 1555. Two of the poems in Harley 1703 have recently been transcribed by Milsom (2010, esp.35$36,37-38$, from fols $62 \mathrm{v}-63,33 \mathrm{r}-\mathrm{v}$ respectively).

${ }^{23}$ See MacCracken $(1909,110-11)$; the poem is on fols $79 \mathrm{v}-80$. On the misattribution see most recently Dunbar (1998, II, 30).

${ }^{24}$ His full name appears only three times at the end of particular poems: "haec gulielmi fforest" (fol. 62), “Qd. W. fforest .1571." (fol. 66), "deo gratias Willm forest" (fol. 106); at
} 
(c) ederi 29 (2019)

In total eight manuscripts survive containing Forrest's works. What makes these manuscripts particularly distinctive is that they were all copied by Forrest himself. He has left a far larger body of autograph verse than survives for any other sixteenth-century English poet. In several of these manuscripts he specifically identifies them as copied in his own hand. Royal 18 C. xiii is described as "per me Guilelmum Forrestum manu propria conscriptum" (Fig. 1); elsewhere he describes his work as copied by "Wyllyam Forrest, Preiste, proprie manu" (Bodleian, Wood empt. 2, fol. 69v). In other manuscripts he subscribes his work simply "per me Gulielmum Forrestum" (Harley 1703, fol. 153) or "Quod william fforest" (Bodleian, Eng. poet. d. 9, fol. 157).

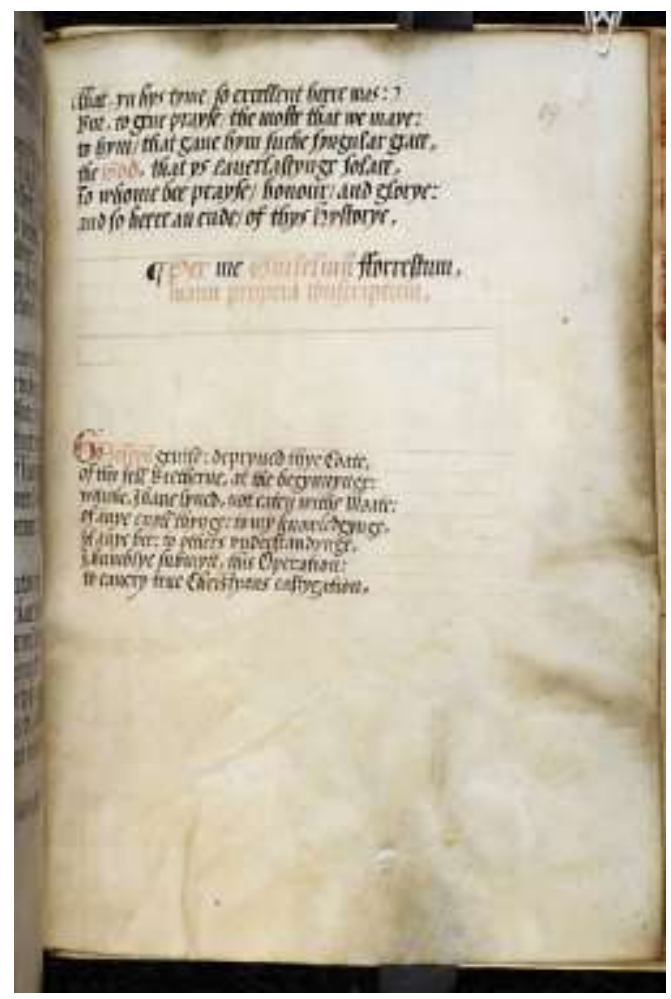

Fig. 1: @ British Library Board MS Royal 18 C. xiii, fol. 19

several other points he gives his initials at the end of poems: "finis Amen W. F" (fol. 98), “Amen finis W. F.” (fols 100, 101v). 
To the burden of composition then was added the labor of transcription and also (probably) of related tasks. Such labor was clearly not inconsiderable in view of the number of his manuscripts, the length of his texts and the often-high level of their production values. Five of the eight are copied on vellum, ${ }^{25}$ and a number are also decorated, some quite elaborately. Forms of decoration range from various forms of penwork initials, ${ }^{26}$ to illuminated one ${ }^{27}$ to occasional illustrations. ${ }^{28}$ Whether Forrest himself was the creator of all these forms of visual enhancement is unresolvable. But the possibility cannot be discounted. If he did undertake all of this decoration himself, including the illuminated initials and illustration, it would be very unusual testimony to his comprehensive grasp of the range of skills associated with manuscript production.

The deployment of such skills, whether personally exercised or supervised, seems to have been controlled by an overall shaping sense of what constituted the forms in which his works should be read. The unfinished Pleasaunt poesye of princelie practise, in Royal 17 D. iii, begun in 1548, fairly early in Forrest's career as scribe and poet, shows a careful attention to decorative aspects, notably the elaborate painted initials that recur through much of the text (they disappear towards the end) and the consistent use of rubrication and of words written with different colored letters. The elaborateness of its decorative program seems designed to reflect both the seriousness of its topic, kingship, and the status of its dedicatee, Somerset. It appears to be carefully conceived to offer, in effect, a physical form appropriate for presentation to one who holds the power that forms the subject of the poem. Here the poet/scribe/artist is deployed in an overtly political role not just through the content of his work, but also through the nature of its materiality. Through an unintended irony the manuscript's incomplete state also starkly demonstrates the hazards of such political involvement in the form of [through] the

\footnotetext{
25 These are British Library, MSS Royal 17. A xxi, Royal 17. D. iii, Royal 18. C. xiii, Bodleian Library, MSS University College 88 and Wood empt. 2.

${ }^{26}$ As occur at the start of each chapter in Royal 18. C. iii.

${ }^{27}$ As occur in Royal 17. D. iii.

${ }^{28}$ There is a full-page drawing of Forrest presenting his manuscript to the young Edward IV at the beginning of Royal 17. D. iii.
} 
circumstances that may have entailed its incompleteness, that is, Somerset's fall from power in 1549.

Similar elaborate decoration occurs in Bodleian Library MS Wood empt. 2, the unique copy of Forrest's History of Grisild the Second. It seems likely that this manuscript was intended for presentation to Mary Tudor. It is on vellum and carefully ruled for four spaced rhyme royal stanzas to a page. Each of the twenty chapters begins with an elaborate painted initial; proper names are rubricated. Once again there is a sense of an effort to create a form of the work appropriate for the status of the dedicatee or commissioner. Such a sense of appropriateness extends beyond the text. The original binding was in black velvet (now virtually disappeared) with four bosses, each inscribed "ave Maria gracia plena" thereby linking dedicatee directly to the form of Christian faith she so forcefully embodied.

The standard of decoration achieved in Forrest's earlier manuscripts is not sustained in the later ones. It may be that in later life Forrest either had less access to necessary resources or less ability to execute decoration and (perhaps) less ready access to patrons eager for lavish copies. Both Eng. poet d. 9 and Harley 1703 are on paper and without decoration; as already noted, these were completed in 1569 and 1572 respectively.

Forrest's concern with the visual aesthetics of his works finds related expression in the central element in his autograph creations, his transcriptions. Crucial here is his ability to deploy a hierarchy of scripts in the same manuscript. In Royal 17 D. iii, for example, The Pleasant Practise of Princelie Poesie, the distinction is less a matter of size or form of script than of duct. There is a contrast between his upright display script, with alternate lines in different colored inks, which is used in title and dedication, and his regular slightly right leaning text hand, largely written in black ink. ${ }^{29}$ The page also reflects an evident concern with spacing and the proper overall balance of the page, seen in the employment of different hierarchies of decorated initials, with a larger (7-line) one to mark the beginning of the text itself. The chief paleographical characteristics of both scripts are the two lobed -glinked by a vertical short vertical ascender, the lower lobe not invariably fully closed; single compartment -a- with a left turning hooked ascender; open -e-; and the absence of any forms of ligature

${ }^{29}$ See the facsimile of fol. 8 reproduced in Manzalaoui $(1997,400)$. 
apart from -st-, -th-, such double consonants as -ff- and -11-, and forms involving -g- and a following letter: -ge-, -gh-, -gn-,-go-, -gr-. It is a distinctive hand; the consistency in its forms and the regularity of aspect demonstrate a kind of visual authority, one that is made the more distinctive by the transitions between black and red inks, often in alternate lines, with [but] red [is] also used to give emphasis to proper names.

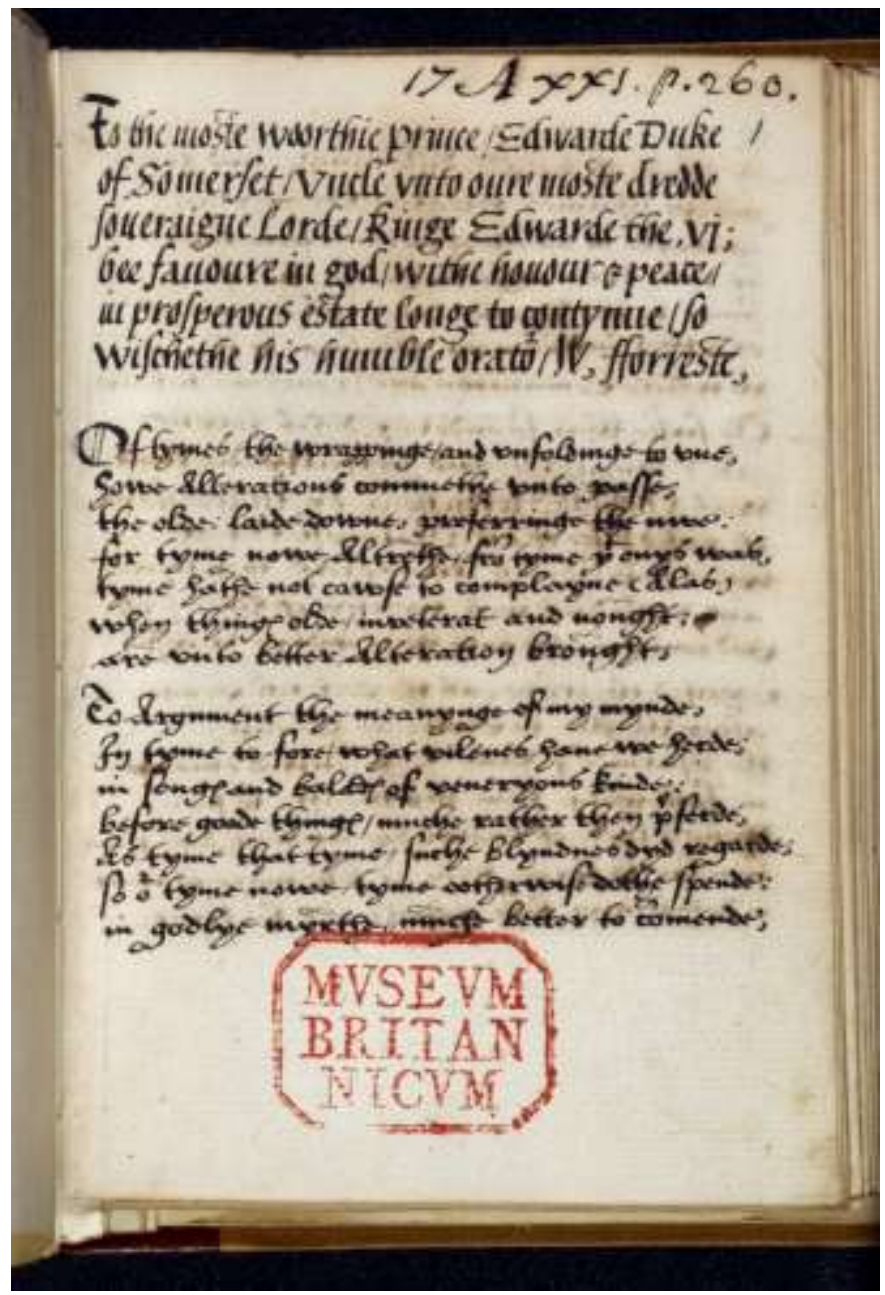

Fig. 2: @British Library MS Board Royal 17 A. xxi, fol. 5 
One can contrast the handling of script here with that in the other manuscript that Forrest dedicated to Somerset in Royal 17 A. xxi, fol. 1 , where the categories of script appear unsupported by any decorative elaborateness (Fig. 2). There is an obvious distinction between the larger display script of the title heading ("Certaigne Psalmes of dauyd $\left.[\ldots]^{\prime \prime}\right)$, where size and lack of ligatures between letters provide the chief means of emphasis, and the smaller, fluent cursive script of the text itself, where only the opening word is emphasized in heavier ink ("Come [sic], let vs singe vnto the lorde $\left.[\ldots]^{\prime \prime}\right)$. But there is a modulation between these forms through the use of another, thinner form of display script ("Heere doothe the propheat call us all $[\ldots]^{\prime \prime}$ ) clearly written with a sharper nib.

The conception of the relationship between forms of script and page layout, here and elsewhere, serves as a reminder of the relationship, famously formulated by Stanley Morison (1972), between script and politics. It is clear that Forrest, writing in an age primarily of print, took such forms of representation as a serious element in the "delivery" of individual copies of his works in manuscript to particular prominent figures, both Catholic and Protestant, from Mary Tudor herself and Thomas, duke of Norfolk on the one hand, to Protector Somerset, and the reformist (or opportunist) William Parr, earl of Essex, on the other. The careful balancing of such a range of scripts in these presentation copies, together with the use of different colored inks and illumination, shows an awareness of the relationship between the visual and the verbal. The evident aim is to create a series of harmonious visual effects through which what is being said is consonant in its written forms with the status of the envisaged audiences.

It is unclear how Forrest developed his skills as a scribe. It is possible that he was trained in a monastery in his youth. If so, there may be a parallel with Andrew Borde (ca. 1490-1549), who began his career at the start of the sixteenth century as a scribe in the London Charterhouse, copying vernacular religious writings; his name occurs as copyist in Bodleian Library, MS Douce 262, in a colophon to a copy of the Book of Privy Counselling. But whereas Borde went on to a prolific career in print, the trajectory of Forrest's activities was very different. It is also possible that he may have had connections to the secular manuscript book trade. As I have said, he can be linked to the poet Alexander Barclay, whose will includes bequests to his cousin Parnell 
Atkinson and to her husband Thomas Atkinson, described there as a London scrivener. ${ }^{30}$ This tenuous connection between Barclay, Forrest and metropolitan commercial scribal activity in the mid sixteenth century can offer no more than a reminder of the contexts in which manuscript production could obtain at this time. ${ }^{31}$ But it is a reminder worth having in relation to Forrest even if it brings no greater clarity about the ways in which he developed his scribal and decorative skills.

It is not easy to find precedents for Forrest's activities as a scribepoet. The most apposite is probably the work of the Augustinian monk, John Capgrave (1393-1464), who in the fifteenth century also made a number of copies of his own writings intended for presentation to specific, often powerful, individuals and who apparently oversaw a scriptorium producing further copies. ${ }^{32}$ Capgrave's activities are the only precedent in England for a religious vernacular poet preparing numbers of copies of his own works personally for prestige audiences. There are, however, significant differences between the two. Forrest, of course, found himself in circumstances where such monastic resources were no longer available and where he must have had to find other means to produce his works. Thus, he embodies a model of literary entrepreneurship that has no obvious contemporary parallels in the number and often the quality of his manuscript productions. Forrest seems to have combined in one person forms of literary activities that, in later periods, were to require distinct organizational categories: author, production manager and literary agent, as he negotiated the preparation of bespoke manuscript versions of his writings.

The last category remains the most intriguing and the most unclear. Given their often relatively high production standards it seems likely that the majority of his manuscripts were commissioned. Even if Forrest undertook all aspects of decoration himself, as well as acting as scribe, the expense of acquiring vellum, colored inks and paint, would have been considerable. And if he did not, but drew on

\footnotetext{
${ }^{30}$ On Barclay's relationship with Atkinson see Orme (2008).

${ }^{31}$ For a fine overview of manuscript circulation in this period, see Woudhuysen (1996); this does not, however, discuss Forrest.

32 On Capgrave's activities see Lucas (1969); this is reprinted in revised form in his From Author to Audience: John Capgrave \& Medieval Publication (1997, 19-68).
} 
the services of other artisans, these expenses would have been correspondingly greater. That he could have borne the attendant expenses himself seems unlikely. As is often the case, the dynamics of subvention, or patronage, if that is what it was, resist confident analysis. But the most likely implication is that Forrest had access to networks that could provide material support for at least some of his manuscripts, most probably from those to whom works were dedicated. Such expensive investments in manuscript production were uncommon by the middle of the sixteenth century. They offer testimony to the level of attention Forrest devoted to creating forms of his poems that were personalized through the integrated activities of poet, scribe and decorator(s) (possibly all the same person) to meet his sense of a precisely defined audience.

Forrest appears to have appreciated that in a print culture there were still audiences for such highly personalized manuscript productions. And that the demand for such manuscripts cut across political and religious divisions, embracing both Catholic and Protestant circles, finding audiences among those in positions of power in different regimes.

This is not the place to raise the question of the nature of Forrest's literary achievement. Any assessment of it would be premature since, as already noted, no significant part of his corpus exists in a reliable modern edition. But it is clear that those of his writings intended for presentation to persons of political standing generally articulate a coherent moral vision in which personal history often becomes exemplary biography, emblematic of the constancy of virtue in an unstable world and the operation of Divine justice. These matters can be seen in obvious ways in the variant forms of his Life of Joseph, composed for different prominent Catholics in the reigns of Henry VIII and Elizabeth I, and his account of the injustices meted out to Mary Tudor's mother in his History of Grisild the Second. Both Katherine and Joseph are victims of a world in which they experience extreme loss, ingratitude and injustice nobly borne and triumphantly transcended through faith and God's will. ${ }^{33}$ But Forrest's interests also extend to obvious devotional ends in his manuscripts concerned with Psalm translation and Mariolatry as well as to more immediate issues

${ }^{33}$ The two figures are explicitly linked in the "Oration consolatorye" addressed "To the Queenys Majestie," with which The history of Griseld the Second concludes: "So hathe the wicked disquieted thee, | (O noble Queene!), as the like Joseph dyd" (ed. Macray, p. 158). 
of Realpolitik. In the only partially completed work of political instruction that he addressed to Protector Somerset, he presents himself as guide and counsellor proffering sage guidance.

Forrest's dedications of a number of his works to specific individuals may also reflect his awareness of changing political and religious circumstances and a final withdrawal in later life from involvement in such matters. His latest work, from the early 1570s, the transcription of a variety of poems treating of the Blessed Virgin, has no named dedicatee and may reflect a wholly personal devotional piety. The contrast here between the less elaborate form of this collection in comparison to his earlier manuscripts may be suggestive of such a retreat to private reflection.

Evidently Forrest was both a poet of some versatility and a scribe of considerable proficiency. In the latter respect he shows himself to be capable of deploying a range of scripts and (possibly/probably) decorative techniques, and adept at integrating text into a larger sense of page design. The market for his productions was largely precisely targeted to those in positions of power. His production of such manuscripts over several decades for persons of prominence across a spectrum of politics and faith in the mid sixteenth century shows some of the ways in which the manuscript form continued to be applicable in such contexts. Forrest's activities suggest the continuing existence of a demand for high end personalized manuscript books, books designed for coterie audiences, within an established print culture. That he was able to identify and serve such a manuscript market and to disseminate his own verse through it in such bespoke forms as survive makes him a curious manifestation of late English scribal and clerical literary culture. A fuller appreciation of the interrelated roles he enjoyed as both poet and artisan may contribute to a broader understanding of the potentiality of the manuscript book at a relatively advanced stage in its history.

\section{References}

Bentley, T. \& B. Walford. 1687. Bibliotheca illustris: sive catalogus variorum librorum.... Libris Rarissimis tam Typis Excusis quam Manuscriptis refertissimæ: Quorum Auctio habebitur Londini... Novemb. 21, 1687.

Bergsagel, John D. 1963. "The Date and Provenance of the Forrest-Heyther Collection of Tudor Masses." Music and Letters 44: 240-48. 
Bernard, Edmund. 1697. Catalogi librorum manuscriptorum Angliae et Hiberniae.

Census-Catalogue of Manuscript Sources of Polyphonic Music, 1400-1550. 5 vols. 1979-1988. Neuhausen-Stuttgart: Hannsler Verlag.

Digital Image Archive of Medieval Music [DIAMM]. Accessed July 1, 2019. https://www.diamm.ac.uk/sources/2285/\#/

Dunbar, William. 1998. The Poems of William Dunbar. Edited by Priscilla Bawcutt. 2 vols. Glasgow: Association for Scottish Literary Studies.

Emden, Alfred B. 1974. A Biographical Register of the University of Oxford A.D. 1501 to 1540. Oxford: Clarendon Press.

Forrest, William. 1553. A New Ballade of the Marigolde London: Richard Lant. STC 11186.

Forrest, William. 1875. The History of Grisild the Second. Edited by W. D. Macray. London: Whittingham and Wilkins.

Foxe, John. 1563. Acts and Monuments. London: John Day. STC 11222.

Graves, Thomas S. 1923. "On the Reputation of John Heywood." Modern Philology 21: 209-13.

Hanna, Ralph. 2002. A Descriptive Catalogue of the Western Medieval Manuscripts of St John's College, Oxford. Oxford: Oxford University Press.

Holmes, Peter. 2007. "Forrest, William (fl. 1530-1576), poet." Oxford Dictionary of National Biography. 27 Jul. 2019.

https:// www.oxforddnb.com/view/10.1093/ref:odnb/9780198614128.0 01.0001/odnb-9780198614128-e-9892.

James, Montague Rhodes. 1900. The Western Manuscripts in the Library of Trinity College, Cambridge. Cambridge: Cambridge University Press.

Keenan, Joseph Patrick, C.S.C. 1960. "An Edition of the Marian Poems of the Recusant Writer, William Forrest, from MS. Harleian 1703." Unpublished doctoral dissertation, University of Notre Dame.

Ker, Neil R. 1937-1938. “Membra Disiecta." British Museum Quarterly 12: 13435.

Lucas, Peter. 1969. "John Capgrave, Scribe and Publisher." Transactions of the Cambridge Bibliographical Society 5 (1): 1-35.

Lucas, Peter. 1997. From Author to Audience: John Capgrave \& Medieval Publication. Dublin: University College Dublin Press.

MacCracken, Henry Noble. 1909. “New Stanzas by Dunbar.” Modern Language Notes 24: 110-11.

Manzalaoui, M. A. 1997. Secretum Secretorum: Nine English Versions. EETS 276. Oxford: Oxford University Press.

Mehok, Edward Eugene. 1971. "An Edition of William Forrest's 'History of Joseph'." Unpublished doctoral dissertation, Case Western Reserve University. 
Edwards

Milsom, John. 2010. “William Mundy's 'Vox Patris Caelestis' and the Accession of Mary Tudor." Music E Letters 91: 1-38.

Morison, Stanley. 1972. Politics and Script: Aspects of Authority and Freedom in the Development of Graeco-Latin Script from the Sixth Century B.C. to the Twentieth Century A.D. Edited and completed by Nicolas Barker. Oxford: Clarendon Press.

Orme, Nicholas. 2008. "Barclay, Alexander (c. 1484-1552), poet and clergyman." Oxford Dictionary of National Biography. 27 Jul. 2019. https://www.oxforddnb.com/view/10.1093/ref:odnb/9780198614128.0 01.0001/odnb-9780198614128-e-1337.

Robinson, J. Armitage, and M. R. James. 1909. The Manuscripts of Westminster Abbey. Cambridge: Cambridge University Press.

Sylvester, R. S., ed. 1959. The Life and Death of Cardinal Wolsey. EETS 243. London: Oxford University Press.

White, Beatrice, ed. 1928. The Eclogues of Alexander Barclay. EETS, o. s. 175. London: Oxford University Press.

Wood, Anthony. 1691. Athenae Oxonienses. London: Thomas Bennet. Wing W 3382.

Wort, Oliver. 2016a. "A Cuckoo in the Nest? William Forrest, the Duke of Somerset, and the Certaigne Psalmes of Dauyd." Reformation 21: 25-46.

Wort, Oliver. 2016b. "Dating William Forrest's The Second Grisilde." Journal of the Early Book Society 19: 65-96.

Wort, Oliver. 2017. "Dating William Forrest's The History of the Patriark Joseph." Philological Quarterly 96: 203-18.

Woudhuysen, Henry. 1996. Sir Philip Sidney and the Circulation of Manuscripts, 1558-1640. Oxford: Oxford University Press.

Young, Alison. 1964. "Bledlow II-Church and Parsons." Records of Buckinghamshire 17: 367-85.

How to cite this note:

Edwards, A.S.G. "William Forrest: Poetry, politics, script and power." SEDERI 29 (2019): 163-78.

https://doi.org/10.34136/sederi.2019.7

Author's contact: A.S.G.Edwards@kent.ac.uk

Postal address: School of English - Rutherford College - University of Kent - Kent, CT2 7NX - UK

Submission: 16/01/2019

Acceptance: 26/03/2019 